Archaeological Journal

\title{
Notes on Symbolic Animals in English Art and Literature
}

\section{J. L. André F.S.A.}

To cite this article: J. L. André F.S.A. (1891) Notes on Symbolic Animals in English Art and Literature, Archaeological Journal, 48:1, 210-240, DOI: 10.1080/00665983.1891.10852477

To link to this article: http://dx.doi.org/10.1080/00665983.1891.10852477

曲 Published online: 15 Jul 2014.

Submit your article to this journal $\pi$

Q View related articles $\longleftarrow$ 


\section{NUTES ON SYMBOLIC ANIMALS IN ENGIISH ART AND LITERATURE. ${ }^{\prime}$}

By J. L. ANDRE, F.S.A.

However erroneous it may now be considered, the theory of Creation held during the Middle Ages, was both beautiful and noble, and in a fairly accurate manner may be summarised as follows. On the fall of the tenth legion of the citizens of heaven, God resolved to create man to take the place of the fallen Angels $;^{2}$ he evolved this world for the home of his new creation, and all things that he then made, the celestial bodies, the vegetable and animal kingdoms, were formed solely and entirely for man alone, ${ }^{3}$ as the centre round which the whole of creation revolved. There was no idea then that the world in which man was placed formed only one of many such inhabited homes, or that our sphere was simply an insignificant fragment of a vast universe. The celestial bodies, it was held, were created not only to give light and heat, to generate metals and precious stones, but to govern the affairs of men and enable them to foretell events. The vegetable kingdom was to furnish food and medicine not only for man's body but likewise for his mind. Lastly the animal creation provided him with servants, with food for his bodily wants, and with moral lessons and examples for those of his soul. This I venture to advance as a tolerably accurate summary of the theory of Creation held during the Middle Ages, and until nearly the close of the seventeenth century, and if correct, it will appear from it that each part of creation was viewed not only in an outward and material manner, but also in an interior and spiritual one.

1 Read at the Montbly Meeting of the Institute, June 4 th, 1891.

2 rompare Milton Paradise Lost, book vii, lines $146,159$.

3 See Faber, The Precious Blood, p. 11. 
The observations now proposed to be made refer only to the ideas formerly entertained of the moral lessons supposed to be derired from the animal creation, as then understood, though many creatures then fully believed in, are now proved to be fabulous. The examples will be taken from all periods of English art, but the literary ones will principally be confined to passages in the works of the sixteenth and seventeenth century writers; and this for two reasons, in the first place to show how tenaciously Ehe old theories were adhered to, and in the second, Gecause I consider that hitherto the writers on animal Eymbolism have for the most part drawn their illustrations from the Bestiaries of mediæval authors, and similar sources.

Before proceeding to consider each animal separately, a Lew words may be said on the opinions held of them colEectively. In the first place animals were believed to have Been all tame before the fall of man. Milton describes Weir gambols, and Spenser writing of the "antique age," "The lyon there did with the lambe consort,
And eke the dove sat by the faulcon's side;
Ne each of other feared fraud or tort.
But did in safe security abide,
Withouten peril of the stronger pride."

After the fall, they began to make war with and devou each other, as we are informed in Paradise Lost, and either

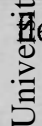

"With count'nance grim, Glar'd on him passing."

Many quaint ideas were connected with the beasts in foah's Ark. Elfric in his Anglo-Saxon Homilies tells us off this vessel, that "In the lowermost bottom dwelt the ence beasts, and creeping worms. On the second flooring twelt birds and clean animals. On the third flooring dwelt

1 Milton says of Adam and Eve in paradise:-

About them frisking play'd

All beasts of th' earth, since wild, and of all thase

In wood or wilderness, forest or den ;

Sporting the lion ramp'd, and in his paw

Dandled the kid; bears, tigers, ounces, pards,

Gambol'd before them; th' unwieldly elephant

VOL, XLVIII
To make them mirth us'd all his might, and wreath'd

His lithe proboscis;

Paradise Lost, book iv, 340, 347.

2 Spenser, Faerie Queene, book iv, canto 8 .

3 Milton, Paradise Lost, book x, 713, 714. Animals were considered as, to a certain extent, participants in man's guilt. See Leviticus $\mathrm{xx}, v, 16$, and Jonah III, v. 7, 8.

$2 \mathrm{E}$ 
Noah and his wife and his three sons with their three wives. In the bottom the ark was roomy, where the fierce beasts dwelt, and narrowed above, where the dwelling of men was; for the holy church is in fleshly men very broad, and in spiritual narrow. She spreads her bosom where the rugged dwell in brutal habits, and she is narrowed at the end which the discreet inhabit, living in spiritual practices ; for the holier they are in the present church, so the less of them there is."

As three of the evangelistic symbols are formed of animals, it may perbaps be permitted to say a few words upon them here, whilst treating of the animal creation collectively, rather than to notice them in connection with the respective creatures to which they belong. Dating from Saxon times the use of these emblems seems nover to have entirely died out, as they may be found in Sturt's Orthodox Communicant, an engraved book, published in 1721. They are to be seen on the Norman font at Castle Frome, Herefordshire, and it need hardly be said were great favourites on similar vessels of Perpendicular date. Another frequent use of these symbols was to employ them on the four sides of buildings; the cruciform monastic barn at Glastonbury has them on each gable; they are on four corbels of the nave roof at Felmersham, Beds, and also on the faces of the tower at S. Neots, Hunts. ${ }^{2}$ The emblems separately are not often found on painted screens, but there is an example at S. Mary Magdalen's, Wiggenhall, Norfolk. In company with their respective saints they are very frequently met with. Usually each evangelist has his appropriate symbol at his feet, but at Potter Heigham, Norfolk, S. Mark carries his lion in his arms, and has a scroll with the words "Recumbentibus indicem dis(cipulis)," a departure from the usual practice of each writer bearing a ribbon with the commencing words of his gospel. At East Ruston, also in Norfolk, the screen has the figures of the evangelists with their usual emblems, except that of $\mathrm{S}$.

1 Homilies of Aflfric, vol. i, p. 537, ed. Alfric Ed 1843. The ark with its occupants is sculptured at Nerwich and Salisbury Cathedrals, in both, I believe, the arrangement shows the beasts in the lowest stage, the men in the middle division, and the birds in the upper.
Hildebert, according to $\mathrm{Dr}$. Neale, explains the symbolism of the ark in a very similar manner. See Mediceval $H_{y m n s, \text { p. } 104 .}$

2 At Wiggenhall S. Peter, Norfolk, the evangelistic symbols formed the pinnacles of the tower. 
Matthew, who appears as an angel in kingly robes, Armine-tippeted, doubtless in allusion to his tracing, in his i) Oospel, the royal descent of our Lord from David and "\$olomon.' Nettlestead Church, Kent, has some stained dlass representing "the emblem of S. John under the inusual type of an angel with the head of an eagle. "Figures of the evangelistic symbols," says Mr. Winston, "with human bodies, the heads being those of animals, by vhich the evangelists are typificd, occur in mediæval art, $\mathrm{s}$ in frescoes by Barnaba da Modena."2 The glass here alluded to he supposes to be about the time of Henry VI. Having discussed symbolic animals collectively, I will ] now proceed to the consideration of individual members of the animal creation, taking them alphabetically in the five divisions of beasts, birds, fishes, reptiles, and chimerical or fabulous creatures.

if I. BeAsts. Among these the Ass is an emblem of patience, and also of stubborness and stupidity; as an exponent of the latter characteristics, it is represented at Hawton, Notts, where two of the sleeping soldiers at the Easter sepulchre are seen with asses' heads braying, as charges upon their shields, in allusion to the foolishness and obstinacy of the Jews. As an emblem of patience it appears occasionally in heraldic art the families of Askew, Hackwell, Hokenhall, and others having the ass as a charge in their arms, Spenser says that-

\footnotetext{
"Sluggish idlenesse, the nurse of sin;

Upon a slouthfull asse he chose to ryde."3
}

At Pengarwick Tower in Sydney Cove, Cornwall, there is, I believe, the following verse painted under the picture of a laden ass-
"Behold this asse which laden ys
With riches, plentye, and with meate
And yet thereof no pleasure hathe
But thystells hard and rough doth eat,
In lyke case ys the riche niggarde
Which hath enoughe and lyveth full harde."

A Norman capital in the Museum of the Society of Antiquaries, from the old hall at Westminster, represents the fable of Esop concerning the ass. ${ }^{4}$

'The Dominican saint, Vincent Ferrar, is represented with angel's wings. 166.
3 Spenser, F. Q., book i, canto 4.

4 Transactions Soc. Antiquaries, Catalogue, vol, i, p. 28. 
The CAMEL or Dromedary, was also an emblem of patience and likewise of avarice. The figure of one is seen many times repeated on the tomb of a deacon at $\mathrm{S}$. John's, Glastonbury, and in heraldry it occurs in the Arms of the Camel and Wheeler families. Camels form the supporters of the Arms of the "Confraternity of S. John Baptist of Merchant Taylors," of London, as it is still called; doubtless a quaint allusion to the camel's hair clothing of its patron. The camel was said to be ashamed of its ugliness, so that when drinking at a stream it would trouble the water in order to avoid seeing its own image. Swan, a seventeenth century writer, from whom I propose to make numerous quotations, finds in this an emblem of those who "drink deeply of the dirtie puddles of worldly wealth, little regarding the sweet taste of the waters of life, which is a clear river running from the throne of God."' He also sees in the hump upon this animal's back, the swelling pride and confidence of rich worldly men. Nevertheless after these two unfarourable inferences he perceives a good symbol in the fact of the camels stooping "down to the very ground with their knees, patiently enduring, to take up their burdens," and calls it a lesson of patience and humility such as shown by those who are "willingly humbled under the crosse and patiently stoop to take it up." "Spenser says of Luxury, that-

\section{"Greedy avarice by him did ride, \\ Upon a camell loaden all with gold." 3}

Among DeEr, the hind is an emblem of solitude, and as such, two of these animals are seen by the side of S. Withburga on the rood-screen at Burlingham S. Andrew, Norfolk. S. Giles often has a deer leaping up to him, as at Great Plumstead, and Sandringham, Norfolk, and Cheddar, Somerset. Swan mentions their custom of "flying to man when the hounds oppresse them" as an emblem of those who betake themselves to God in their affliction. Their careful teaching of their young he considers a symbol of the solicitude which parents show for

1 Spcculuin Mundi by John Swan, Cambridge, 1643 , p. 437. Segneri, all Italian Jesuit, in his Quaresimale, pub. in 1679 , snys of the wicked "They behive like camels, who cannot bear to see themselves reflected in the clear stream, and accordingly trample the water with their feet and make it turbid; such a hardship does it appear to them to be thus compelled to gaze upon their own doformity." Vol. i, p. 133, Ford's Translation.

2 Swan, pp. 437, 438 .

3 Spenser, F. Q., book $i$, canto 4. 
their children; in their weeping every year for the loss a of their horns he sees a likeness of those who grieve for f the loss of their worldly possessions. He tells us that the "hart when taken by the hunters "will shed forth tears as cwell as when he casteth his head. So should a penitent fand a watchful sinner not cease to weep when he seeth how he is overtaken." Shakespeare alludes to the stag weeping-

\section{". . The big round tears \\ Cours'd one another down his innocent nose In piteous chase."}

Sylvanus Morgan calls the stag the symbol of long life, and as such it was usually considered, though now discredited. It was also believed to be attracted by musical sounds, an idea portrayed on the cciling at Blickling Hall, Norfolk, where the plaster work has figures of a man and woman playing upon instruments before a listening stag. ${ }^{3}$

The legend of S. Hubert repor's him to have seen a miraculous stag bearing a cross between his horns. The device of an antlered stag's head with the cross between the branches occurs on the armorial bearings of the families of Hadd, Quickerell, Serffe and Wryne. The Boughtons have three bucks' heads between as many crosses, perhaps allusive to the stag of S. Hubert, or that of S. Eustace, of whom a similar story is related.

Like many other animals the Dog bears both a good and an evil character, and is symbolical of loyalty and fidelity on the one hand, and of all that is wicked on the other. His bad reputation dates from very early times, and in the Hebrew Scriptures he is, with one or two solitary exceptions, always alluded to in the must uncomplimentary manner. This animal was regarded with aversion by the Jews, but amongst the Greeks he was treated as the companion of man and held in much esteem. ${ }^{4} \quad$ The dog has always been an especial favourite in England, though in symbolic art his figure appears but seldom. In monumental sculpture the little dogs which are so often seen beneath the feet of the effigies of ladies, crouching on their dresses, may occasionally have been thus placed as types of affection and faithfulness, but

1 Swan, pp. 473, 474.

2 "As You Like It," act ii, sc. i.

${ }^{3}$ See Antiquary, vol. i, p. 249.
4 The description of Ulysses dog Argus, in the Odyssey, bouk xvii, will be remembered by the reader. 
were most probably generally so used as natural objects ; especially as they are often derorated with collars hung with bells, and sometimes with the names of the animals themselves written upon them. ${ }^{1}$ 'The dog, as an emblem of affection, is said to be seen supporting the bowl of the font at Staple Church, Kent.

The ornamental andirons supporting the logs of our wood fires are called fire-dogs; in like manner the French term them "chenets" a contraction of "chien-ets," and I venture to suggest that this appellation, similar in both languages, may have arisen from the Roman Lares, or household gods, whose emblem was the dog, a symbol given these deities on account of this creature's fidelity, and the service it renders to man in watching his house. The Lares were also occasionally represented as clothed in dog's skins. From this, it appears probable that the terms "fire-dog" and "chenet" may have been derived, as moreover, the Romans used ornamental andirons, a pair of which were found in a sepulchre at Shefford, Beds. ${ }^{2}$

There was a notion held by old writers that a dog would run after and bite a stone thrown at him rather than chase the man who threw it. Spenser says of a hag that she "did bark" and backbite--

\footnotetext{
"Though there were none her hatefull words to heare ;

Like as a curre doth felly bite and teare

The stone, which passed straunger at him threw." "s
}

The ERmine, a kind of stoat, was an emblem of purity, and died of grief, if its white fur became stained; for this reason it is still used as the trimming of our judge's robes. It is the distinctive fur of royalty and authority, and is sometimes seen on the dress of the B. Virgin to show her queenly dignity, as at Somerleyton, Suffolk. As a mark of high position the robes of the Lord Mayor of London, and those of kings and emperors at home and abroad, exhibit ermine trimmings.

Probably there is no other animal which has taken so prominent a part in symbolism and fable as the Fox. Of the subtilties, of this beast an old author writes, "they

1 Instead of the usual pet dog, a squirrel cracking a nut is seen upon the folds of the mantle of Lady Katharine Howard, on her brass, dated 1535, at Lambeth, Surrey.
${ }^{2}$ See Ass. Arch. Soc. Reports 1850. 1851 , p. 167.

3 Spenser, F. Q., book iv, canto 8 . 
he infinite ;" and certainly the stories told of his cunning - ppear to be endless. Philip de Thaun tells us that the f ox was accustomed to lay on his back and cover himself with red earth, pretending death, to allow birds to come find eat his flesh; so says this twelfth century author, and Swan in the seventeenth states the same, as follows :"When cold and hunger shall oppresse him, coming near some farm or mansion house, he feigneth a kind of barking like a dogge, that thereby the household beasts may more confidently keep themselves without fear, being often used to the barking of a dogge ; and so having gotten himselt near unto his prey, he will lie upon his back, with his belly upwards, mouth open, tongue out, and every way seeming as if he were dead; then the hens, or geese, or what else is fit for him, are suddenly surprised, and cunningly caught, whilst they little dreamed of such a subtiltie." I The Norman doorway at Alne in Yorkshire represents a fox pursuing the above tactics, with the word, "vulpis" over the panel.

Chaucer's "Nonnes Preestes Tale" is a serio-comic one, respecting the cunning fox, Dan Russel, who induces Chiaunteclere the rooster to sing before him-

"This Chaunteclere stood high npon his toes
Stretching his neck, and held his eyen cloos,
And gau to crowen londe for the nones :
And Dan Russel the fox stert up at ones
And by the gargat hente Chaunteclere,
And on his back toward the wood him bare."

Foxes and geese are said by Mr. Paley to occur on some E:trly English capitals. ${ }^{3}$ The satirical representation of the fox preaching to geese is met with in many ecclesiastical buildings, as at Bristol Cathedral and Christchurch, Hants, on the misereres; a secular example was carved on the Half Moon Inn at Ipswich. The same subject.was also in stained glass at S. Martin's, Leicester, where the satire was made more pointed by the text "Testis est mihi Deus quam cupiam vos omnes in visceribus meis ;" words addressed by S. Paul to the Philippians, with a change in the last word, "God is my record, how greatly I long after you all in my bowels"; instead of "the bowels of Jesus Christ." A coffin slab at Bridlington, Yorks, has a representation of

1 Swan, p. 440.

2 Chaucer Cant. Tales, p. 456, ed. Routledge. is Manual of Gothic Architecture, p.110.

4 G. A. Poole in Ecclesiologist, vol, $\mathbf{x} \nabla$. 
the fable of the fox and the stork, ${ }^{1}$ whilst at Sherburn the geese are seen hanging their old enemy the fox, from a gallows, and at Nantwich the stalls shew us Reynard turned monk, or rather a wandering friar with habit and hood.

Notwithstanding the doubtful character of the fox, it is occasionally met with in heraldry, and forms the crests of the Blennerhasset and Fox-Strangway families.

Of that well-known emblem of the reprobate, the GOAT, Aubrey writes as follows :- "A conceit there is that ye devil coñionly appeareth $\mathrm{w}^{\text {th }}$ a cloven hoof, wherein, though it seem excessively ridiculous there may be something of truth, and $\mathrm{y}^{\mathrm{e}}$ ground at first might be his frequent appearing in the shape of a goat $\mathrm{w}^{\mathrm{ch}}$ answers that description. This was the opinion of ancient Xtians, concerning $y^{\mathrm{e}}$ apparition of Panites, Fauns, and Satyrs." "The devil," he continues, "mnst often appears in the shape of a goat nor did he only assume this shape in elder times, but commonly in later times, especially in $y^{0}$ place of his worship, if there be any truth in the confession of witches. And therefore a goat is not improperly made an hieroglyphic of $y^{e}$ Devil, as Pierius hath expressed it. So might it be an emblem of sin as it were in the sin offering, and so likewise of wicked and sinful men according to $\mathrm{y}^{\mathrm{e}}$ expression of scripture in $\mathrm{y}^{\mathrm{e}}$ methnd of $\mathrm{y}^{\mathrm{e}}$ last distribution, when our Saviour shall separate the Sheep from the Goats, that is the Sons of the Lamb, from the children of the devil." Spenser places Luxury-

"Upon a bearded gote, whose rugged heare,

And whally eies (the signe of gelosy),

Was like the per'son's self whom he did beare." 3

Like the Goat, the Honse was a symbol of wickedness, and there is a boss at Norwich showing the raven sent forth from the ark, feeding upon the dead body of a horse, as an emblem of destroyed sinfulness. The evil character of the equine tribe was doubtless derived from the Scriptures, and probably occasioned the eating of horse-flesh to be considered a deadly sin amongst the early Christians of Scandinavia, one of whom writes that "it is the greatest sacrilege for baptized men, who can in any other

1 It was also on a Norman capital at S. Margaret's, York. See Reliquary, vol. ii, N.S., p. 10.

2 Aubrey. Remains of Gentilisme and
Judaisme, p. 113, ed. Folk Lore Soc., 1881.

${ }^{3}$ Spenser, F. Q., book i, canto 4. 
manner prolong their lives, to eat horse-flesh." "In England at the Council of Cealchythe, it was a subject of complaint that many persons "eat horse-flesh, which is done by none of the Eastern Christians," and they are bidden to "take heed of this." " Ven. Bede, relating an incident in his "Life of $\mathrm{S}$. Cuthbert, says, respecting an angel who appeared seated upon a horse of incomparable beauty:- "If any one think it incredible that an angel should appear on horseback, let him read the history of the Maccabees, in which angels are said to have come on horseback to the assistance of Judas Maccabeus, and to defend God's own temple." 3 Angels upon horses may be noticed upon the Steeple Aston cope.

The Hyend was another symbol of evil passions. Swan says of it " (as the magicians would have us believe) this beast hath the power of incantation; they therefore tell many strange things which they be able to do." Spenser, describing a hideous beast, informs us that-

\footnotetext{
"Like never yet did living eie detect;

But likest it to an hyena was,

That feeds on wemens flesh, as others feede on gras."
}

A work called "An English Expositour," issued in 1680 , by John Hayes, Printer to the University of Cambridge, says of the Hyena, that it "will counterfeit the voice of a man to draw the shepherds out of their houses in the night, to the end he may kill them. It is written, that he changeth sex often, being sometime male, and sometime female." 6

The LAMB is the most sacred and prominent of symbolic quadrupeds, and employed during all epochs of the Christian faith. The lamb, with cross-headed staff and triple-ended banner, was a great favourite in Norman work, and in numerous cases it appears amid figures of all kinds of animals, real or imaginary. Occasionally the nimbus has three crosses upon it, which I venture to suggest refers to the parlicipation of each person of the Holy Trinity in the Redemption of mankind; such an aureole is seen over the head of this symbol on the

1 Olaf Tryggvason Fornmanna Sogur c. I. quo. Du Chaillu The Viking Age vol. $i$, p. 474 . 56.

2 'Townley, Bib. Literatu'e, vol, i, p.

vor. XLVIII
3 Bede Vita S. Cuthberti, ed. Giles. Chap. II.

4 Swan, p. 438

5 Spenser, F. Q., book iii, canto 7

- Enq. Expositour article Hyena. 
Norman doorway at S. Michael, Barton le-Street. In the very early paintings formerly at Westmeston, Sussex, the sacred lamb appeared in the centre of a quatrefoil over the chancel arch; this enclosure was upheld by two angels with averted countenances as though unable to bear the effulgence of the divine glory. The eastern boss of the groining of S. Leonard's Church, Kirkstead, a work of Early English date, has the lamb and flag, the staff of the latter terminating in a richly floriated Greek cross; and at Luton, Beds, the curious Third Pointed baptistery has on its roof the vine of the church, attacked by the dragon, and defended by the lamb. '

When the lamb is the emblem of St. John Baptist, it is occasionally depicted as a natural representation, reposing upon a closed book in the hands of the saint, as at Belaugh, Norfolk; at other times the symbol is within one nimbus, whilst a smaller one encircles the head of the Agnus, as on the Southgate House antependium.

In heraldry the Agnus dei is borne by the Lamberton family, and in a remarkable manner by that of Rowe, Sussex, who have three holy lambs for their arms and another for their crest. A holy lamb formed the arms of Sir John Duntze of Tiverton, Devon, and is the crest of the Merchant Taylor's Company of London, being the symbol of the patron S. John.

The Lron, king of beasts, and the well-known emblem of courage, nobility and generosity, has. unlike the lamb, also an evil reputation as a type of the devil. Our Lord, as the lion of the tribe of Judah, appears upon a boss at Norwich. As emblems of divine strength a lion is seen on either side of the lamb at Upleaden Church, Gloucestershire, and as symbolical of the vigour given in baptism, these animals appear on many fonts, especially those of the opening and elosing periods of Pointed Art; of the former period there is a fine example at Hereford Cathedral, where four lions cluster round the base of the Norman font. At Swanscombe, Kent, and S. Peter's Ipswich, the bowls are entirely covered with these kingly beasts. In Perpendicular work, especially in the eastern counties, a great number of fonts have lions sejant round their stems,

1 The sacred lamb is met with occasionally in eighteenth century work, it occurs on the tombstone of Will Plyear, 1783, at Brading, I. of Wight, 
and this is found so frequently that they must evidently be symbolical, and not merely heraldic figures, especially as they are often combined with woodhouses, or wild men, who are thus placed as emblems of courage and strength; the woodhouse being probably the mediæval antitype of the Satyrs.' The number of lions on some examples is remarkable, as for instance at Worlingham, Suffolk, where there are five panels on the bowl filled with these animals whilst four more cluster round the stem, almost rivaling in number the lions placed about the throne of King Solomon. Lions are frequently met with at the bases of lecterns as at S. Margaret's, Lynn, and Holy Rhood, Southampton.

As emblems of strength we often find lions and oak trees combined in English medirval art. Thus, in an inventory of the vestments at $\mathrm{S}$. Paul's Cathedral in 1552, mention is made of several articles embroidered with "lions and oketres," and on an antependium of the fifteenth century the subjects are divided by oak branches beginning and ending in lions' heads; in like manner the martyrdoms worked upon the Steeple, Aston cope, have lions in the spandrils between them, and the subjects surrounded by oak foliage and acorns. A curious heraldic illustration of this combination is seen in the arms of Atwood, of Norfolk, and Surrey, which exhibit a lion rampant on a field semée of acorns.

It was believed of lions that the colder the place of their abode, the gentler they were, that they spare women rather than men, and prey not at all upon infants except in case of much hunger. Also that they would not devour a sleeping man, a notion we find in Shakespeare, when in "As You Like It," he mentions a bush, under which a lioness -

6: Lay crouching on the ground with cat-like watch When that the sleeping man should stir ; for t'is The royal disposition of that beast,

To prey on nothing that doth seem as dead,"

\footnotetext{
1 A ubrey writes of "The Signe of the Wild Man," as follows :- "This signe is not uncommon in and around London. I confess I wondered heretofore how such an odd signe should happen to be so in vogue, but by Rudbecki Atlantica $I$ find it to be from the
}

Suedes," He then quotes the above author to the effect that "The Suedes had Hercules for a deity." Remaines of Gentilisme, \&c., p. 134, ed. Folk Lore Soc.

2 Act iv, sc. 6. 
The lion had a great antipathy to the game cock for which it was stated, "one reason is that he sees him commonly with his crowne on his heade, while princes commonly are jealous of each other." 1

The PANTHER was an emblem of Christ, and as Philip de Thaun says, loved of all the animals except the dragon. At Alne, Yorks, one sees the panther and his foe face to face. Swan makes him the emblem of deceit, and as such it appears on the Jacobean ceiling at Blickling, Norfolk, with the word "Dolos" or cunning. Dryden in his Hind and Panther makes the latter the symbol of the Church of England. ${ }^{2}$

SwINe are emblems of all kinds of depravity and of its author; figures of swine alternated with those of dragons are placed under the knights who are seen guarding the shrine of S. Thomas Cantelupe at Hereford Cathedral. The devil and his fellows were very naturally supposed to occasionally take the form of swine. Shylock tells Bassanio, in the Merchant of Venice, that he refuses " to eat " of the habitation, which your prophet the Nazarite, conjured the devil into." Spenser places gluttony by the side of idleness and riding upon a "filthie swine."

The Trges is considered an emblem of cruelty, and it was said of this beast that when the hunters take her whelps away, "sometimes they make round spheres of glasse which they cast before her when she cometh, and thinking (by reason of her own shadow) that she seeth her young ones there, she rolleth it to her denne, where she breaketh it with her claws, and finding herself deluded runneth after the hunters again." The arms of the Lightwood family have three tigers beholding themselves backward in a glass, and a similar device occurs on the armorial bearings of the Tatersals $;^{5}$ both coats probably being in reference to the above legend.

Among symbolical BrRDs, the Cock, as an emblem of watehfulness, is sculptured on the Saxon Church at Bar-

: Strange Metamorphosis, \&c., 1634 ; quo Braud Pop. Ant., vol. ii, p. 56.

2 The Scripture prophecy that the lion should lie down with the lamb, furms the subject of a Sussex eighteenth century fireback.

3 Spenser, F. Q., book i, canto 4.

1 Sw气 n, p. 435. See Arch. Journal, ol. xxxi, p. 377 .
See also Arch. Journal, v. xxxiij, p. 400 , on a carved box-wood casket, of which one compartment represents a countryman carrying away the young of a beast, having distracted her attention by fixing a dise in a tree.

5 See Berry, Enc. of Heraldry, vol. i, p. 62, and Pabyan's Chronicles, p. 587. 
nack; and cocks are placed over the Norman doorwaya $t$ Little Bytham, Lincolnshire. ${ }^{1}$. As a vane this bird has surmounted our church spires for more than a thousand years, and was fixed there, not only as a symbol of vigilance, but to incite the clergy to watch over their flocks as the rooster does over his hens. ${ }^{2}$ The cock, as one of the emblems of the Passion, is conspicuous on the head of the Perpendicular church-yard cross at Sherbourne, Yorkshire, where on either side of the Saviour are scutcheons, one of which bears the lantern, the other a cock's head, both symbols being allusive to the betrayal and denial of our Lord. The kingly lion was supposed to be kept in awe by the shrill voice of the game cock.

The Dove, the emblem of the Holy Ghost and of innocence, Aslfric tells us, "is a very peaceful and innocent bird, and without gall, and not fierce with its claws; nor lives it on worms, but on earthly fruits." Swan remarks that if man was like this bird, without gall, "the serpent's wisdom would not, hurt him, nor leanfaced envie sojourn with him." "This symbol of the Holy Spirit is sometimes seen whispering into the ear of our T.ord, in representations of the Trinity, as at Cheriton, Kent. Doves of the Holy Ghost were on tunicles at S. Paul's Cathedral in 1552, according to the inventory then made. The dove is sometimes placed over the head of King David, as well as above those of saints of the new dispensation. ${ }^{5}$

In Norman work the symbol of two doves drinking from one vessel, a frequent device in early Christian times, is occasionally met with, as on a monumental slab at Bishopstone, Sussex, and the fonts at Winchester and East Meon, Hants; it occurs also on later encaustic tiles. Dr. Lee in his Glossary says, "Figures of doves as appropriate ecclesiastical symbols were-suspended over English

I Paley's Manual, p. 52.

2 "Gallus regit plurimam turbam gallinarum,

Et solicitudines magnas habet barum :

SicSacerdos, conciprens curam animarum, Doceat et faciat quod deo sit carum.

Gallus gramen reperit, convocat uxores,

Et illud distribuit inter cariores :

Tales discant clerici pietatis mores,

Dando suis subditis scripturarum flores."
From a fifteenth century MS., quo Ecclesiologist, vol. $\mathrm{xi}$, pp. 161, 162.

${ }^{3}$ Homilies of Elfiric, vol. ii, p. 45, ed. Aslfric Soc., 1845 .

${ }^{4}$ Swan, p. 401.

${ }^{5}$ A symbolical representation of $S$. Mary at South Leigh, has the dove descending upon her. Arch. Journal, vol. $\mathrm{xxx}, \mathrm{p}$. 58. A dove whispers into the ear of S. Gregory in a painting at Tunstead, Norfolk. 
baptisteries, and are sometimes found carved on the canopies of fonts. As symbolic representations of the Holy Spirit they are likewise carved over altars, and sometimes, as on the brass corona at Thame Church, Oxfordshire, they symbolize the Light and Glory of God."'

The dove also represents the innocent soul, and as such is the emblem of S. Medardus, at whose funeral "two white doves from heaven floated over his coffin and a third came out of the coffin and flew with the others to the skies." The collect for the feast of S. Scholastica, in the Sarum Missal, states that, God caused her soul " to enter heaven in the form of a dove," an assertion founded on a vision of S. Benedict, her brother. The cope of Pius II., an English Work, shows the souls of the five philosophers converted by S. Catharine and afterwards martyred, as five white doves flying upwards. At Breedon, Worcestershire, on the remarkable Second Pointed monumental stone in the churchyard, there are represented two doves between the figures of the persons commemorated, probably as emblems of their souls.

The king of birds, the EAGLE, is an emblem of the Holy Ghost, and one of the symbols of S. John the Evangelist. It took up its offspring in its claws and bore it as near the sun as it could soar; if the eaglet bore the sun's rays without flinching, it was legitimate, if not and it shunned the glare, the parent dropped the bird which was dashed to pieces on the ground. Shakespeare touches on this belief when Richard of Gloucester says-

"Nay, if thou be that princely Eagle's bird,

Shew thy descent by gazing 'gainst the sun."'

and Dryden exclaims in his Britannia Rediviva -

"Truth, which is light itself, doth darkness shun, And the true eaglet safely dares the sun." 4

The eagle appears as a representative bird in the seven days of Creation, sculptured on the bosses of the nave roof at Norwich Cathedral, and an eagle and a lion are placed by the side of our Lord and His mother at Fownhope. This bird so often seen upon our lecterns, is sometimes said to be there as an emblem of S. John $;^{5}$ but to me it

1 Lee's Glossary of Liturgical and Ecclesiastical T'er'ms, pp. 89, 90.

\& Barr's Anglican Calendar, p. 261.

33 Henry VI, act ii, se. 1.

+ Quoted in Miss Strickland's Lives of the Queens, vol. v, p. 51.
5 Boutell's Heraldry, p. 140 . A writer in the Ecclesiologist, vol. i, p. 173, suggests that the eagle desk mily symbolize "the angel flying through the midst of heaven having the everlasting gospel to preach." 
appears to be intended as a symbol of the Holy Ghost. especially as it sometimes stands upon a serpent, as at Holy Rhood Church, Southampton, and very frequently it is upon a globe, representing the world, as at $\mathrm{S}$. Margaret's, Lynn.

The double headed eagle, the emblem of Elisha, is seen on his shoulder in stained glass at Lincoln College Chapel, Oxford; this figure was sometimes embroidered upon vestments, an instance of which may be noticed in a cope formerly at Weston Underwood, Northants. In heraldry it was a frequent charge and appears on a shield attached to the effigy of one of the Salaman family, at Horley, Surrey, a fourteenth century example of much beauty.

The PEACuck was an emblem of the resurrection and immortality in early Christian art, but in the heraldry of later times became that of pride and conceit. Swan calls it "a perfecte embleme of deep envie." He states that "his black feet make him ashamed of his fair tail, and therefore when he seeth them-he hangeth down his s'arrie plumes and walketh slowly in a discontented fit of solitarie sarlnesse." "Lions and Pecokkys" are mentioned as being on a vestment at S. Margaret Patten's, London, in 1470.

From very early Christian times the Pelican has been a favourite symbol of our Lord, and appears never to have been entirely disused. But the ancient and modern id aas concerning this bird differ; the present notion is that it feeds its young with its blood, the ancient that it revived them with it, as Swan rightly puts it, "by piercing his breast he reviveth his young ones with his own blood wlien they are bitten and killed of serpents; or having killed them with his bill he reviveth them again by his blood after three dayes." ${ }^{2}$ He also states that they swallow shell fish, and when they have been "so warmed that their shells gape, they do cast them up and so pick out their meat in an easie manner"; from this action he considers pelicans teach that policy is better than strength. The bird often forms an appropriate finial to a font cover, instances of which occur at North Walsham and Watlington, Norfolk, and Ufford, Suffolk. It is used instead of the more frequent eagle on a lectern at Norwich, and was

1 Swan, p. 403.

2 John de Wakering, Bishop of Nor- wich, bore arms azure a pelican vulning herself or. 
formerly so employed at Durham, where it formed the desk of the finest brazen lectern in England. A pelican in her piety is seen on one of the stalls at Lincoln Cathedral, and a beautiful example of the same device forms the finial of the noble brass at. Warbleton, Sussex, dated 1436. A scroll surrounding it bears the significant inscription, "Sic Christus dilexit nos." A very vigorous representation of this symbol is on a boss from the destroyed nave roof at S. Saviour's, Southwark, also of fifteenth century date. An example of eighteen!h century design is found in Sturt's Orthodox Communicant.

The Bambell family have a pelican for their arms and crest, and several other coats have this device which was a great favourite with Fox, Bishop of Winchester, being placed under his statue in the cathedral of that city.

Shakespeare alludes more than once to the pelican. Laertes says in "Hamlet"-

\footnotetext{
"To his good friends thus wide, I'll ope my arms ; And like the kind life-rend ring pelican, Repast them with my blood."l
}

and Drayton in his Noah's Flood versifies the older belief thus-

\author{
"The loving pelican \\ Whose young ones poison'cl by the serpent's sting \\ With her own blood to life again doth bring."
}

An evil reputation belongs to the Raves, who was sometimes called the devil's bird. Perhaps part of its bad character may have arisen from the fact of its being so much employerl by the heathen soothsayers. Tradition says that its colou: was originally white but was changed into black, owing to the bird's disobedience in not returning when sent forth from the ark, but stopping to feed on drowned bodies. In the chapter house at Salisbury and on the roof of Norwich Cathedral the raven is thus seen devouring corpses. It was said that it "picketh out the eye of a dead corps first of all because (as some suppose) he seeth his own image in the clearness of the eye." A fourteenth century M.S., the "Cursor Mundi," says of the raven's exit from the ark-

2 Act $i \nabla$, sc. 5.

${ }^{2}$ Swan, p. 388 . 


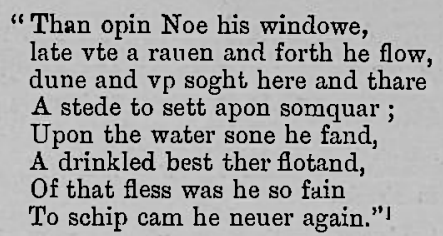

The ancients had another tradition as to the change in the raven's coat and this was that the bird having betrayed two lovers by his indiscreet tale-bearing was thus punished. Gower, who gives the tale at length, says, so

\section{"That there he was snow-white to-fore, Ever afterward cole black therefore, \\ He was transformed!"2}

The same poet tells us that the cry of the raven betokens some misfortune. Swan, that this bird expels its young from its nest before they are "able to shift" for themselves; "wherefore," says he, "it is said that the young ravens crie unto God." Perhaps the motto of the Corbet family, whose arms are a crow, alludes to this, being "Deus pascit corvus," God feeds the raven.

Sincerity and solitude are symbolized by the $\mathbf{S W A N}$, and a figure of this bird occurs on the roof at Norwich, as an intermediate animal between the fish and the bird. It formed the well-known badge of the De Bohun family, and is beautifully figured several times on the elegant brass of Alianor De Bohun, 1399, in Westminster Abbay. l3outell says, one of the earliest indications of the use of heraldic supporters is on the seal of Humphrey de Bohun 1.2.2, where the belt is carried by a swan over the shield. Planche mentions the collar of SS. with this badge of the De Bohuns, as appendant round the neck of the poet Gower in S. Saviour's, Southwark, and in a note, says, "It is singular that among all the ingenious speculations respecting the origin and meaning of the collar of S.S. this pendant of the swan in oue of the earliest examples (1402), sliould never have been taken into consideration." In the "Speculum Mundi," Swan tells us that this bird is a perfect pattern of chaste, mutual, and matrimonial love, and that the dying song of the swan is "a perfect embleme

1 M.S. Gottingen, fol. 26a, quo Alrian and Itithens, ed. Aflfric Soc., p. 203.

VOL. XIVIII
${ }^{2}$ Gower, Confessio Amantis, book iii, p. 150 , ed. Routledge.

${ }_{3}$ Planche, Pursuivant of Arms, p. 188. 
and pattern to us, that our death ought to be cheerful, and life not dear unto us as it is." ${ }^{1}$ Shakespeare discourses of this in the "Merchant of Venice" when Portia says-

"Then if he lose he makes a swan-like end,

Fading in Music."

The symbolism of FisHes forms the next division of the present remarks, and is a highly interesting one, though perhaps not so extensive as the preceding.

As the fish is the well-known emblem of our Lord, in a similiar manner the Holy Trinity is symbolized by three fishes, conjoined, so as to form a triangle. This device is much older than Christianity, and may be seen in Egyptian art. $^{3} \quad$ It occurred on the arms of Yarmouth, and was on a boss at S. Saviour's, Southwark. The figure of our Lord under the form of a fish suggested by his name, naturally created the idea that faithful Christians should likewise appear under the likeness of fishes, especially as Christ commissioned his apostles to be fishers of men. The symbol was the more readily accepted, as the Jews entertained a high opinion of the happiness of fish existence, so much so, that one of their Rabbins, describing the doctrine of the transmigration of souls, inculcated that "the souls of the righteous whose conversation is with the law and, and who only need a purification, go into fish." "In the Saxon church at Barholm, near Stow, Lincolnshire, on the south doorway there is "a curious pattern resembling a row of fish conventionally treated," and on the Norman doorway at Stoneleigh, Warwickshire, is seen "the contest between the faithful under the shape of fishes, and their ghostly enemies under that of serpents and dragons," and at Ely, on a Norman entrance to the Cathedral, our Saviour is seen within the vesica or fish outline, his left hand holding a fish. The square bowl of the font, at Slaugham, Sussex, has the figure of a fish forming the sole ornamentation of one side of the vessel. Of later date, formed in the iron work of the south door, at Staplehurst, Kent, are seen several fishes swimming round the ship of the Church, whilst at West Walton, Norfolk, the clerestory walls have the Church's net

\footnotetext{
1 Swan, p. 406.

2 Act iii, sc. 2.

3 See engraving in $\Delta r t$ Journal, 1864, p. 303 .
}

4 Sharon Turuer, Sacred History of the World, vol. i, p. 205.

5 Ar"ch. Journal, vol. xlvii, p. $151 \mathrm{n}$.

6 HandBook of Eng. Ecclesiology, p.163. 
painted upon them, each mesh of which contains a fish. Mermaids, emblems of sinful pleasures, hold fishes on the font at Braybooke, Northants, and on the stalls at Exeter. On the pall at S. Gregory's, Norwich, may be seen fishes symbolizing the faithful departed, swallowed by dolphins emblematical of love to man.

Swan calls the DoLPEIN the "king of fishes than whom there is not any which is swifter, none more charitable to his fellows, and (which is above all the rest) none more loving to man." The porpoise and the dolphin are generally taken to be the same fish, but although Buffon admits their great resemblance, he says that the snout of the latter is longer and more pointed. The idea of its being a friend to man is of great antiquity, and in early Christian art the monster which swallowed Jonah is often more like a dolphin than a whale. Pliny relates a story of a boy carried to school on its back, which Swan gives at full length, and the so called "acts of S. Julian" contain a legend to the effect that the saint's body was brought to shore on the back of a dolphin. ${ }^{2}$

In heraldry the dolphin, Mr. Boutell says, "was most probably originally used to convey theidea of sovereignty. ${ }^{3}$ I also think that it was so employed as emblematical of brotherly love. Be this as it may, this fish is conspicuous in numerous heraldic coats, especially in those of families connected with sea-port towns. The very appropriate arms of the London Company of Fishmongers, have three dolphins naiant in pale between two pair of lucies saltirewise, over which in chief are three couple of S. Peter's keys, also in saltire, finally the supporters are a merman and mermaid; no more fitting design could have been devised than this.

In the account of the Creation in Genesis the formation of the WHALE is especially mentioned, a fact which old writers prominently dwell upon. Swan remarks that Moses in his description of the creation of the fishes places the greater ones " in the forefront and then he proceedeth to adde something concerning the other species of smaller creatures living and moving in the water."

1 Swan, p. 372.

2 See Arch. Journal, vol. xxix, p. 302.

3 Boutell's Heraldry, p. 138.
4 Swan, p. 359. "Luther commenting on these words 'And God created great whales reudereth this reason why the 
The whale was sometimes symbolical of hell mouth, at others of the devil himself; the Norman sculpture at Lincoln Cathedral shows an example of the former idea, which I need not say is found in numerous later examples, a Decorated one being at Bloxham in Oxfordshire. Notwithstanding the proverbially evil character of the whale, Swan sees a favourable symbol in the care that this creature shows for her young, which he says, "when they are little being faint and weak, she takes them into her mouth to secure them from tempesteous surges-a fit embleme this to teach all sorts of parents in Church Commonwealth, or private families to provide for and not destroy those under them ": he also tells us of the little fish Musculus, a great friend to the whale, and concludes from its example that "great ones and superiors-ought not to contemne their inferiours."

It was a mediæval idea that so large was the whale that sailors mistaking one asleep for an island, would land upon it and light a fire when the fish feeling uncomfortably warm would sink beneath the sea's surface and drown the unsuspecting mariners. Milton relates something very similar, for he reports of Leviathan as follows, that he

$$
\begin{aligned}
& \text { ". Haply slumb'ring on the Norway foam, } \\
& \text { The pilot of some small night-founder'd skiff, } \\
& \text { Deeming some island oft, as sea-men tell } \\
& \text { With fixed anchor in his skaly rind, } \\
& \text { Moors by his side under the lee, while night } \\
& \text { Invests the sea, and wished morn delays."3 }
\end{aligned}
$$

A few Reptules are conspicuous among symbolic animals. In their company may be noticed the CAMELEoN of which Buffon says that if "the iguaua satisfies the appetites of epicure, this is rather the feast of the philo-

creation of whales is specified by name, ne territi magnitudine crederimus ea spectra esse." Lest affrighted with their greatness we should believe them to be only visions or fancies." Fuller's Worthies quo Suss. Arch. Soc. Collections, rol. xxii, p. 41.

1 Some lines under a drawing in a eəpy of the "Bestiary of Philippe cle Thaun," have "Cetus hic pingitur-et quomodo pisces entrant os ejus. . . Cetus diabolum significat-et pisces aminas." -Arch. Journal, i, p. 176.

2 Swan, p. 362.

3 Par. Lost, book i, 203, 208. Besides the fishes mentioned in this article there was another which deserves some mention ; this was the Remora, which Swan says "is a small fish which cleveth to the buttom of a ship, and doth as strangely stay it, called, therefore, by some the "Stop-ship." Of which there can be no more reason given, then (sic) of the load. stunes drawing iron; neither is it possible to shew the cause of all secrets in nature," pp. 375, 376. The English Expositour" repeats the above in substance, and adds " Hence Remora taken generally for any stop or hinderance." 
sopher." He describes at length the curious changes which take place in the colour of this reptile under certain circumstances, but says nothing of the old idea of its being able to live on air. Alexander Ross, a seventeenth century writer against Sir Thomas Browne's "Religio Medici," defends the ancient opinion and asks:- "To what end should it gape more than other animals, but that it stands more in need of air than they for nutrition," Speed in "The two Gentlemen of Verona," says-" Tho" the camelion Love, can live on the air, T'am one that am nourish'd by my victuals." 2 Shakespeare also alludes in another passage to the change in this reptile's colour. Gloster in Hen. VI., boasting that he could "add colours to the Camelion." Gower says that vainglory is

". - Lich unto the camelion,

Whiche upon every sondry bewe

That he beholt he mote newe-

His colour."

Swan is inclined to the opinion that the changes in colour " affordeth a fit embleme, or lively representation of flatterers and time-servers, who fit themselves for all companies times, and occasions." The "English Expositour," is of like mind and says that this "little beast" changeth himself quickly into any colour that he sitteth upon, except white and red; wherefore men that are inconstant and fickle, are sometimes called Chameleons."

Of the CROCoDILE, or Cockodrill, as Mandeville terms it, it was said that when asleep a serpent creeping into its mouth, and then penetrating its stomach, tore it asunder ; in like manner our Lord, clothed with his humanity, burst the bonds of hell and overcame death. ${ }^{5}$ It was formerly believed that if it killed a man, it grieved ever afterwards, so it was reported in the fourteenth century, and Swan in the seventeenth says, "When he hath devoured a man and eaten up all but the head, he will sit and weep over it, as if he expressed a great portion of sorrow for his cruell fact; but is nothing so, it is because his hungrie paunche wants such another prey." "The English Expositour" confirms the above. Shakespeare in Henry VI. says-

1. Quoted Brand, Pop. Ant, vol. ii, p. 368.

2 Act ii, sc. 1.
3 Gower Con. Aman, book i, p. 85, ed. Routledge.

${ }^{4}$ Swan, p. 487.

5 See Reliquary, vol. i, N.S. p. 28. 


\section{“. - Gloster's show}

Beguiles him as the mournful crocodile

With sorrow snares relenting passengers." 1 -

Of the Salamanner it was reported that its constitution was "so cold that (like ice) if he do but tonch the fire he puts it out," and the ancients held that it lived in the flames and fed on fire as its proper nutriment. Buffon says that when thrown into the fire, the animal is seen to burst with the heat of its situation, and to eject its fluids. "We are gravely told," he continues "in the Philosophical Transactions, that this is a method the animal takes to extinguish the flames."

A writer in the "Saturday Magazine," pub. in 1835, writes thus:- "In our own times a strange belief exists among the ignorant that if any fire remains unquenched for seven years, a salamander will be produced." This beast is an emblem of baptism and is sculptured on the Norman fonts at Winchester Cathedral and Bridekirk Church, Cumberland; it is also seen twining round the stem of one at Salehurst, Sussex. It forms an appropriate device upon some old south of England fire-backs, and there is a spirited representation of one on an example in the Lewes Museum, dated 1550. Asbestos was formerly called salamander's wool and believed to be formed of the hair of this animal.

The SconPION bore a bad character. Chaucer in his Merchant's Tale, exclaims-

\footnotetext{
"O soden hap, O thou fortune unstable,

Like to the Scorpion so deceivable,

That llatrest with thy hed, whan thou wolt sting;

Thy tayl is deth, thrugh thin enveniming." 3
}

Swan gravely relates a story of an Italian, who from smelling the herb basil too often, had "a scorpion bred in his brain." The arms of the Coley family exhibit three scorpions.

As a symbolic animal, the Serpent is the chief of the reptiles, and like many others of the animal creation has been used both as a good, and, an evil symbol, as the emblem of wisdom, and of evil and sin. In old representations of the temptation of Adam and Eve, the devil is frequently seen with the head of a woman termina-

12 Henry VI., act rii, sc. 9.

2 Buffon, Nat. History, vol. ii, p. 262, ledge. ed. Kearsley, 1792.

${ }^{3}$ Cant, Tales, 9,900, 9,903, ed. RoutSwan, p. 238. 
ting the serpent in which be is hidden. Ven. Bede talls us that the author of evil when tempting Eve, "chose a certain kind of serpent, having a face resembling a virgin's, because like things delight in their like, and moved its tongue to speak, the serpent at that time knowing nothing of it, in the same way as he speaks by the mouth of fanatics and those who are possessed without their knowledge." 1 An example of the woman-headed serpent may be noticed in the curious bas-relief of Third Pointed date at Bridge, Kent, and another occurs on a boss of the same date at Norwich. Satan appeared in the Cornish miracle plays temp. James I. with a female face and yellow hair. Pope in his "Epistle in Dr. Arbuthnot," writes -

"Eve's tempter thus the Rabbins have exprest

A Cherub's face, a reptile all the rest."

Milton says nothing of the cherub face but makss his serpent, one

\section{“. . that towered}

Fold above fold a surging maze."

Dr. Lee in his "Glossary," says of the pastoral staff, "Its use is of great antiquity, being probably borrowed in the first Christian age from the rod of Moses, the staff of office of the ancient judges, or the sceptre of the king." What is here said as the rod of Moses, suggests that the serpent figure with which the heads of many medirval pastoral staves are embellished, may be symbolical of the miraculous rod of the prophet. Some very early Celtic examples end in two dragon's heads (synonymous with serpent's), and in the Eastern Church, I believe I am correct in saying, the pastoral staff is often surmounted by two serpents. An early specimen of Norman date in the Museum at Newcastle, has a lamb, with a large Greek cross over it, in the head, surrounded by a serpent forming the crook. In a similar manner the beautiful staff found at Wells, Somerset, has S. Michael and the dragon encircled by the serpent. Again, in the Meyrick collecition were two staves, one of which had this reptile round the temptation of Adam and Eve, whilst the other showed the Coronation of the Blessed Virgin, surrounded by the coil of a serpent which ended in foliage, a clever illustration of the Scrip-

\footnotetext{
${ }^{1}$ Quoted Townley, Bib. Lit., vol. i, p. 292. ' See Qlossary, \&c., p. 272.
} 
ture promise to Eve that her seed should bruise the head of the serpent. In the last case the reptile is evidently symbolical of the devil, in the others it would appear to figure the wisdom of the serpent.

At Holy Rhood Church, Southampton, the lectern has an eagle for the book-rest, treading upon a serpent. Serpents were supposed to torment the bodies of the lost in hell, as the Anglo-Saxon poem Elene says, the condemned

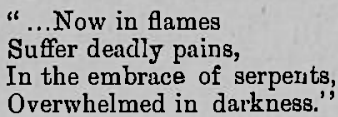

And in the vigorous representation of Hell in the Norman sculptures at Lincoln may be seen many serpent entwined mortals.

The carbuncle was considered to be the noblest of all the precious stones, and to possess the most virtue, it was found in the head of the asp, which, when man would win that jewel by incantation

$$
\begin{aligned}
& \text { "Anone as he perceiveth that, } \\
& \text { He lith doun his one ere al plat } \\
& \text { Unto the grounde, and halt it frste, } \\
& \text { And elie that other ere als faste } \\
& \text { He stoppeth with his tail so sore } \\
& \text { That he the wordes lasse or more } \\
& \text { Of his enchauntement ne hereth } \\
& \text { And :n this wise him selfe he skiereth, } \\
& \text { So that he hath the wordes weived } \\
& \text { And thus his ere is nought deceived." }
\end{aligned}
$$

The tradition of the jewel in the ToAD's head and Shakespeare's allusion to it are too well-known to call for more than a passing mention of them. The opinion that this poor creature is venomous is now quite exploded. Dryden notices the fancy in his "Satyrs of Juvenal," these lines occurring in the first of them,-

"The lady next requires a lashing line

Who squeez'd a toat into her husband's wine."

Spenser makes Envy ride upon a wolf and chew

"Between his cankred teeth a venemous tode."

The Botreaux family bear three toads as their arms.

One of the most conspicuous of the Chimerical or fabulous animals was the BAsIrrsk, Basilcok, or Cockatrice. Swan calls it the "king of serpents, not for its magnitude

1 Gower, Con. Aman., book pp. 55, 56, ed. Routledge. The Python as a symbol of rebellion crushed was repre- sented on a medal struck by Charles I. See Strichland, vol. iv, p. $227 \mathrm{n}$.

2 Spenser, F. Q., book i, canto 4. 
or greatnesse, but for his stately pace and magnanimous mind-among all living creatures," he says "there is none perisheth sooner by the poyson of a Cockatrice than man; for with his sight he killeth him, which is because the beams of the Cockatrice's eyes do corrupt the visible spirit of a man, as is affirmed; which being corrupted, all the other spirits of life coming from the heart and brain, are thereby corrupted also, and so the man dieth. His hissing likewise is said to be as bad, in regard that it blasteth trees, killeth birds, \&c., by poysoning the aire. If anything is slain by it, the same also proveth venimous to such as touch it, only a weasel kills it. Yet though this be a noxious creature, it much magnifieth the power of Gorl, in being able to make such a one by the power of his word." The "English Expositour" gives an equally terrifying account of this serpent and adds that if only a man touch him with a stick it will kill him.

A basilisk with the head and feet of a cock, and the tail of a dragon, occurs on the Norman doorway at S. Margaret's, Walmgate, York. It formed an heraldic charge, and is seen in the arms of the Booth and Buggine families.

Shakespeare has many allusions to the basilisk. In Henry V., Queen Isabel says -

$$
\begin{aligned}
& \text { "Your eyes, which litherto have borne in them } \\
& \text { Against the French, that met them in their bent, } \\
& \text { The fatal balls of murthering basilisks," "I }
\end{aligned}
$$

and in Henry VI., the King exclaims -

"...Come basilisk,

And kill the innocent gazer with thy sight."3

In the same play Suffolk, when cursing his enemies, wishes they may have

"Their cliefest prospect murd'ring basilisks,"

and Gloster boasts that he will "slay more gazers than the basilisk."

Spenser mentions one who

"Secretly his enemiss did slay:

Like as the basilisk, of serpent's seede,

From powerful eyes close venim did consey

Into the looker's hart, and killeth farre away.

: Swan, p. 480 .

2 Act $v$, sc. 2.

y 2 Henry VI, net iii, sc. 6. YOL. XLYIII
4 Ibid, net iii, se. 8.

5 Spenser, F. Q., book iv, canto $b$.

\section{2 म}


The Caladrius was a bird supposed to hover about sick persons. if it looked towards them they recovered, if it turned away its head they died, hence it became an emblem of Christ. This imaginary creature is sculptured on the Norman doorway at Alne, Yorks, with the name C A L A D R I inscribed over it.

In Norman work the Centaur or Sagettary is frequently met with. The hippopotamus appears to have been the animal which suggested the centaur, although its only resemblance to a horse seems to be in its voice. Mandeville says of the land called Bucharia, that "In that country are many ipotaynes that dwell sometimes in the water, and sometimes on the land; and they are half men and half horse, as I have said before, and they ent men when they may take them." A good example of Sagittarius-of Norman date-is on the font at Darenth, and there are two centaurs on the Second Pointed misereres of the stalls at Exeter Cathedral. Planché says, "The Sagittary is said to have been a coat assumed by King Stephen, in consequence of his having commenced his reign under the sign, Sagittarius," but adds, that there is no authority for the charge attributed to Stephen. ${ }^{2}$

The great emblem of the devil-the DraGoN-is probably the most frequently met with of all fabulous creatures, and especially in early northern art. A great number of Cornish fonts of that date have the dragon in some form or other upon them, and it appears upon others at Studham, Beds; Topsham, Devon; and Thorpe Arnold, Leicestershire. In later work at York Minster the head of this monster was carved on the great beam formerly supporting the font cover, ${ }^{3}$ and on the stalls at Lincoln is seen the Christian Knight fighting against seven dragons, typical of the contest of the soul against the seven c.eadly sins. The death of the dragon is sculptured on the Bohn.

1 Early Jiavels in Palestine, p. 261.

${ }_{2}$ Pur. Arms., p. 99. The origin of the Centaur of antiquity is said to have arisen from the mistake of savages, who seeing men mounted on horses for the first time, supposed them one animal ; in later times the same misconception took place in South America. Robertson says of the Spanish sixteenth century adventurers, that their horses " were objects of the greatest astonishment to all the

people of New Spain. At first they imagined the horse and his rider, like the Centaurs of the Ancients, to be some monstrous animal of a terrible form. Even after they had discovered the mistake they believed the horses devoured men in battle, aud when they neighed, thought that they were demanding their prey." - Histon'y of America, vol, ii, p. 525.

3 Rev. Mackenzie Walcott in Builder, 1864, p. 330. 
rood-screen and parclose at Cleeve, Somerset, and at Sherringham, Norfolk, a hideous monster of this kind is in one spandril of the chancel screen and a cockatrice in the other. The brass of Margaret Wylloughby, 1483, at Raveningham, Norfolk, shews her standing on the dragon emblem of her namesake, S. Margaret, an unusual feature in monumental art.'

The seven-headed dragon, the Hydra of antiquity, and the beast of the Apocalypse, is occasionally met with in English symbolism. As the hydra, it forms the crest of the Barret family, and was a device on a fire-back cast at Ashburnham, Sussex; as the seven headed beast of the Revelations, it was depicted on the walls of Lindfield Church, Sussex, where it was exhibited slain by the Blessed Virgin and S. Michael.

The wivern or two-legged dragon enters largely into heraldic art. A standard with this monster is seen on the Bayeux tapestry. It was the crest of Roger de Quincy, Earl of Winchester, and of Thomas, Earl of Lancaster, and it forms the sole charge and crest of the Drake family, a pun on the Latin Draco, or dragon.

One of the most renowned fabulous animals was the GrifFIN, the emblem of watchfulness and forethought, in ancient and mediæval times. At Athens the statue of Athene Parthenos bore a figure of this monster on each side of her helmet, ${ }^{2}$ and the Romans mounted Apollo on a winged griffin. On the Norman font at Darenth is a griffon segreant, and one appears on the horn of Ulphus. The very curious leathern chalice box at Cawston, Norfolk, bears a griffin on the lid. Mandeville writes thus of these animals:- "Some men say that they have the body upward of an eagle and beneath of a lion; and that is true. But one griffin has a greater body, and is stronger than eight lions, and greater and stronger than a hundred eagles."3 Chaucer says of Licurgus-

\footnotetext{
"Blake was his berd, and manly was his face,

The cercles of his eyen in his hed;

They gloweden betwixen yelwe and red,

And like a griffon loked he about.,"
}

\footnotetext{
${ }^{1}$ See Rev. E. Farrer, List of Norfolk Brasses, p. 78.

${ }^{2}$ Perry, Greek and Roman Sculpture, p. 183. The Griffin is seen in Assyrian art.
}
${ }^{3}$ Early Tra. in Pal., p. 261.
1 Chaucer, Cant. Tales, 2 133, 2 136. 
The griffin was the especial guardian of gold and treasures, a fact noticed by Milton, who describing Satan's flight, tells us it was like-

\footnotetext{
'As when a gryphon through the wilderness,

With winged course, o'er hill and moory dale,

Pursues the Arimaspion, who by stealth,

Had from his watchful custody purloin'd

The gruarded gold
}

Swan is cautious about the existence of this animal, and says :- "The griffon is a creature (if there be any such creature for many doubt it) which whether, I may reckon amongst the birds or beasts, I cannot tell." He states that it is "hard to be taken except he be young," and ends his description with a renewal of his scepticism. "But as I said some doubt whether there be any such sreature or no which for my part shall be left to every man's libertie."'

The griffin enters largely into English heraldry, and some families appear to have had an especial fondness for this chimera, the arms and crests of the Evelyns and Finchs, being composed of this fabulous creature.

The Mermaid, in mediæval symbolism, takes the place of the ancient syren of classic lore, and is so well known that little need be said respecting it. The figure is seen in all periods of English art, and was a great favourite, in spite of its being the emblem of the false joys of this world, and of the ruin they bring upon man. The mermaid or merman is used as an heraldic crest, and Berry mentions it as being that of the Chippenhams of Hertfordshire, who have a merman or triton holding a pennon with the word "Jesus" upon it-a singular example. ${ }^{3}$

That extremely rare bird, the Pircenix, was the emblem of Christ and immortality in early Christian art, and of

1 Hilton, Par: Lost, book ii, $943,947$. Marbodus says of the Emerald, "It is found only in a dry uninhabitable country. Through the bitterness of its eold nothing can dwell there 'ut griffins and the one-eyed arimasps that fight with them. By the Emerald we understand those who excel others in the vigour of their faith, and dwell among infidels, who be frigid and arid in love. The griffins that keep watch over them be devils who envy them that have this precious gem of faith, and do their diligence to deprive them thereof, against these fight the one-eyed arimasps, that is those who go not two ways nor have a double heart: nor serve two lords." Quo Neale, Mediceval Hymns, p. 44. See also Arch. Journal, vol. xxxviii, p. 149.

S Swan, p. 386.

3 A naper on the "Mermaid" will be found in The Reliquaiy for October, 1890 . 
the Resurrection of our Lord. It was a belief dating from the earliest ages that there was but one phonix living at a time in the whole world. Shakspeare alludes to this rareness when Rosalind says-

"She calls me proud; and that she could not love me,

Where man as rare as phœnix."

But in the latter part of the sixteenth century the reality of such a bird as the phœnix was much doubted. Sebastian in "The Tempest," says-

\author{
". . Now I will believe \\ That there are unicorns; that in Arabia \\ There is one tree, the phœnix throne ; one phœnix \\ At this time reigning there."?
}

Sir Thomas Browne says, "That there is but one phœnix in all the world, which after many hundred years burns herself; and from the ashes thereof riseth up another, is a conceit not new, nor altogether popular, but of great antiquity, not only delivered by liumane authors, but frequently expressed by holy writers, by Ciril, Epiphanius, and others, by Ambrose in his Hexameron, and Tentullian in his excellent tract, 'De Resurrectionis Carnis.' All which, notwithstanding we cannot presume the existence of this animal, nor dare we affirm there is any phoenix in nature." ${ }^{3}$ Swan doubts of the existence of this bird "that whereas the Lord said to all his creatures, Increase and multiplie, this benediction should take no place in the phœnix which multiplieth not. And again seeing all creatures which came into the Ark came by two and two, the male and female it must needs follow that the phonix by this means perished." 4 Notwithstanding the doubtfulness of the reality of this creature in some seventeenth century writers, two feathers from the tail of this bird were in Tradescant's Museum.

The phœnix appears on one of the misereres in the Lady, or Henry VII. Chapel, Westminster, and at Canterbury Cathedral, round the walls of Becket's crown, were "numerous paintings of a phœnix rising from the flames," which Mr. Keyser conjectures were "probably intended to illustrate the many occasions on which the cathedral had been destroyed by fire,"5 The phœnix forms an

1 As you like it, act iv, sc. 3.

2 Tempest, act iii, sc. 3.

3 Quo Brand, Pop. Antiquities, vol. iii, p. 366 .

4 Swan, p. 385. The Phønix was an emblem of celibacy and for this reason became the badge of Queen Elizabeth. s Arch. Journal, vol, xxxv. p. 279. 
appropriate device on some Sussex firebacks, one of which, dated 1664, is in the Museum of the Sussex Archæological Society at Lewes.

The UNICORN, or licorne, as it was termerl in former times as in modern French, was the emblem of our Saviour, and of purity. It is sculptured with other animals on the horn of Ulphus; as the emblem of our Lord it appears on a boss at Norwich, and it nestles in the lap of the Virgin on one of the stalls at Lincoln Cathedral. In heraldry the unicorn was the symbol of extreme courage, as according to the legend it would rather cast itself off a rock, and die than be taken by the hunters. Planche says that it was "one of the most favourite fabulous animals of the middle ages, but is rarely met with as a coat of arms. As a crest or supporter it is of more frequent occurrence." " Yet Berry gives a list of thirty-five coats, in which the unicorn holds a prominent place. As a crest it appears on the monument of one of the Dalyngruge family at Fletching, Sussex, about 1395 in date. An exhaustive and interesting paper on the symbolism of this animal, by the Rev. Joseph Hirst, will be found in vol. xli. of the Archceological Journal. ${ }^{2}$

'The above are only a few notes on one branch of a most interesting subject. The symbolical animals of the nations of antiquity, as well as those of our own country in past times, together with those of the various peoples of the East at the present day, offer a subject worthy of deep and careful investigation, ancl if the remarks, here made, induce any of my hearers to enter more fully into it, the object of this paper will be duly attained.

P.S.-The symbolic figure painted on the wall near the kitchen of Winchester College, has beneath it the following inscription:
A Trusty Servants Portrait would you see,
This Emblematic Figure well Survey :
The Porkers Snout-not Nice in diet shows,
The Padlock Shut-no secrets He'll disclose.
Patient the Ass-his Masters wrath will bear
Swiftness in Errand-the Staggs Feet declare.
Loaded his Left Hand apt to Labour Saith,
The Vest his Neatness Open hand his. Faith.
Girt with his Sword, his Shield upon his Arm,
Himself \& Master He'll protect from harm.

1 Pur. of Arms., p. 100.

2 Swan is especially indignant with those who refuse to believe in the unicorn. "But," he says, "that there is such a peculiar beast the Scripture, both in Deuteronimie, Isaiah, Job, and the Book of Pealmes doth bear us witnesse," p. 429. 